\title{
Weight Gains and Economy of Production of Weaner Pigs Fed Diets Containing Fermented Mixture of Cassava Root Pulp and Palm Kernel Cake as Replacement for Maize
}

Nnanyere Okwunna Aladi ( $\square$ nnanyerealadi@gmail.com )

Federal University of Technology Owerri https://orcid.org/0000-0002-1871-1789

Sylvester Marro Ukosa

Federal University of Technology Owerri

Ifeanyi Prince Ogbuewu

Federal University of Technology Owerri

Ifeanyi Charles Okoli

Federal University of Technology Owerri

Ndukwe James Okeudo

Federal University of Technology Owerri

\section{Research Article}

Keywords: solid state fermentation, cassava, palm kernel cake, weaner pigs, performance indices, returns on investment

Posted Date: June 28th, 2021

DOI: https://doi.org/10.21203/rs.3.rs-555630/v1

License: (c) (i) This work is licensed under a Creative Commons Attribution 4.0 International License.

Read Full License 


\section{Abstract}

The need to improve the nutritive value of feed materials containing high levels of non-starch polysaccharides (NSPs) such as lignin, cellulose, mannan among others for monogastric feeding has led to interest in solid state fermentation (SSF) in recent years. In this study, the efficacy of SSF to improve nutritive value of mixture of grated cassava roots and palm kernel cake for pig feeding was evaluated using 40 unsexed crossbred (Large White X Nigerian Indigenous) weaner pigs. The pigs were randomly allotted to five treatment groups and fed experimental diets in which the maize in the control diet was partially $(50 \%)$ or completely replaced with either solid state fermented mixture of grated cassava root and palm kernel cake (FEMCARPP) or a 1:1 blend of cassava meal and palm kernel cake (CSM-PKC). Data was collected weekly on the live-weight, weight gain, feed intake and feed conversion ratio, and efficiency of protein utilization. The pigs on dietary FEMCARPP consumed significantly $(p<0.05)$ less feed but had superior weight gain and similar feed conversion ratio when compared to the control pigs fed maize based diets. In addition, pigs fed dietary CSM-PKC consumed significantly $(p<0.05)$ more feed and were less efficient in utilizing their feed. It is therefore concluded that solid state fermentation improved the nutritive value of mixture of grated cassava roots and palm kernel cake for swine feeding. Further research is however needed to extend the study to growing-finisher phase and to understand the physiological mechanism of the improved performance of the piglets on dietary FERMCAPP.

\section{Introduction}

In many countries of sub-Saharan Africa (SSA), there is an increasing demand for and use of unconventional feeding materials to replace maize as feeding materials for pigs. This demand rose primarily due to increasing cost of maize grains in a region which have scarcely produced enough grains to feed its growing population, and meet the needs of her industries for brewing, etc. (Uchegbu et al., 2011; Amata, 2014). The increased use of some of these materials such as cassava by-products and palm kernel cake, wheat offal, fruit processing waste, etc. (Adesehinwa, 2009), has not only created value for but has also reduced environmental pollution resulting from the indiscriminate disposal of these seemingly waste products of agricultural processing in the environments (Wadhwa et al. 2015). The use of these nonconventional feed materials in monogastric feeding is however limited by poor digestibility due to their high contents of NSPs. To sustain the positive outcomes resulting from their use, it has become necessary to develop technologies and products which will improve their digestibility and hence nutritional value. One of such technologies is fermentation. The use of fermented feeds as a biosafe method of improving the quality of feeds for animals has been reported (Brooks et al. 2008; Niba et al., 2009a). These fermented feed materials are usually rich in lactic acid bacteria (LAB) and short chain fatty acids (SCFAs) and may confer on them some probiotic potentials (Niba et al., 2009a, Niba et al 2009b). The advantages of solid-state fermentation over submerged fermentation in improving nutritive quality of feed for pigs have been reported (Choi et al., 2011a). Solid state fermentation (SSF) is one in which the microbes are cultured on a moist solid in near absence of free-flowing water. The efficacy of solid-state fermentation in improving nutritive quality of feed materials for pigs have been reported (Choi 
et al., 2011a). In our previous studies, we have successful demonstrated that a solid state fermented mixture of freshly grated cassava roots and palm kernel cake have physicochemical characteristics similar to maize (Aladi et al., 2013), and the product can successfully replace maize in broiler chicken diets without any deleterious effect of carcass and meat quality of broilers and pigs (Aladi 2016, Chukwukaelo et al., 2018). In this study therefore the efficacy of the solid-state fermented mixture of grated cassava roots and palm kernel cake for replacing maize in diets of growing pigs was evaluated using economics of production and performance indices.

\section{Materials And Methods}

\section{Experimental animals and design}

A total of 40 (20 intact males and 20 females) crossbred (large White x Nigerian Indigenous) piglets farrowed at the Teaching and Research Farm of the Federal University of Technology, Owerri, Nigeria, were used for the experiment. The piglets were weaned at 35 days of age with mean weight $4.53 \pm 0.13$ $\mathrm{Kg}$ and stabilized for one week prior to the experiment. During this period, the piglets were fed a maizesoybean based creep diet formulated to provide $21 \%$ crude protein and $2508 \mathrm{Kcal} / \mathrm{kg}$. At 40 days of age, they were prophylactically treated for ecto and endo parasites by subcutaneous administration ivermectin (Ivomec $\AA$ ) at $0.05 \mathrm{ml} / \mathrm{kg}$ live weight. At 42 days of age, they were randomly assigned to the five treatment groups of 4 males and 4 females each. Two piglets of the same sex within a treatment were housed and fed together in a pen with dimensions $(2 \mathrm{~m} \times 2.5 \mathrm{~m})$. The feeding trial lasted for 6 weeks (from $42^{\text {nd }}$ to $85^{\text {th }}$ day of age).

\section{Feed raw material and diets formulation}

The FEMCARRP was produced following the method described by Aladi et al. (2013). The PKC was pulverized by running it on a locally fabricated hammer mill with sieve size of $0.2 \mathrm{~mm}$ and then mixed with freshly grated cassava tubers in a ratio of $1: 3(\mathrm{w} / \mathrm{w})$. The mixture was then transferred into high density polyethene bags, compressed to exclude as much air as possible and then sealed. The mixture was allowed to ferment for six (6) days before use. Five experimental weaner diets were formulated as shown in Table 1. Diet A (control) contained $44 \%$ maize and in diets B and C, the maize was replaced with $50 \%$ and $100 \%$ FEMCARPP, respectively. In diets $D$ and $E$, maize was replaced with $50 \%$ and $100 \%$, respectively, of a 1:1 blend of cassava root meal and palm kernel cake (CRM-PKC). To ensure the moisture content of all the experimental diets was similar, an amount of water equivalent to the weights of maize in diet A was added to diets A, D and E while half the same amount was added to diet $B$ prior to feeding.

\section{Growth performance}

The pigs were weighed individually at the beginning of each week; each treatment group was allowed a daily supply of feed equivalent to $5 \%$ of their total body weights. All feed left over was collected in the evening $(6.30 \mathrm{pm})$, air dried and weighed and the difference between the feed given and the weight of 
feed leftover was calculated. Data was collated on weight gain, feed intake, feed conversion ratio on replicate basis

Table 1: Ingredients and calculated chemical composition of swine weaner diets

\begin{tabular}{|llllll|}
\hline Test Material & Maize & \multicolumn{2}{l}{ FEMCARPP } & \multicolumn{2}{l|}{ CSM-PKC mix } \\
\hline Diets (Replacement level of maize) & A $(0 \%)$ & B (50 \%) & C (100 \%) & D (50 \%) & E (100 \%) \\
\hline Maize & 44.00 & 22.00 & 0.00 & 22.00 & 0.00 \\
\hline Cassava meal & 0.00 & 0.00 & 0.00 & 11.00 & 22.00 \\
\hline Palm Kernel Cake & 0.00 & 0.00 & 0.00 & 11.00 & 22.00 \\
\hline FEMCARPP & 0.00 & 22.00 & 44.00 & 0.00 & 0.00 \\
\hline Soya bean meal & 20.00 & 20.00 & 20.00 & 20.00 & 20.00 \\
\hline Wheat offal & 28.00 & 28.00 & 28.00 & 28.00 & 28.00 \\
\hline Fish meal & 4.00 & 4.00 & 4.00 & 4.00 & 4.00 \\
\hline Bone meal & 3.00 & 3.00 & 3.00 & 3.00 & 3.00 \\
\hline Lysine & 0.25 & 0.25 & 0.25 & 0.25 & 0.25 \\
\hline Methionine & 0.25 & 0.25 & 0.25 & 0.25 & 0.25 \\
\hline Mineral / Vitamin premix* & 0.25 & 0.25 & 0.25 & 0.25 & 0.25 \\
\hline Salt & 0.25 & 0.25 & 0.25 & 0.25 & 0.25 \\
\hline Total & 100.00 & 100.00 & 100.00 & 100.00 & 100.00 \\
\hline Calculated chemical composition & & & & & \\
\hline Crude protein (\%) & 19.64 & 20.96 & 22.15 & 19.86 & 20.08 \\
\hline Metabolizable energy (Kcal/kg) & 2461.04 & 2262.45 & 2063.85 & 2391.74 & 2322.44 \\
\hline Crude fibre & 5.34 & 7.17 & 8.99 & 9.53 & 13.72 \\
\hline Calcium & 1.29 & 1.34 & 1.39 & 1.34 & 1.39 \\
\hline Phosphorus & 1.17 & 1.27 & 1.37 & 1.27 & 1.37 \\
\hline Lysine & 0.95 & 1.08 & 1.22 & 1.08 & 1.22 \\
\hline Methionine & 0.27 & 0.37 & 0.47 & 0.37 & 0.47 \\
\hline
\end{tabular}

FEMCARPP- Fermented mixture of grated cassava tubers and palm kernel cake *Premix formulated to supply per kg diet: Vit. A 10,000,000 IU; Vit. D3 2,000,000 IU; Vit. E 8,000 IU; Vit. K 2,000 mg; Vit. B1 2,000 mg; Vit. B2 5,500 mg; Vit. B6 1,200 mg; Vit. B12 12 mg; biotin 30 mg; folic acid 600 mg; niacin 10,000 mg; 
pantothenic acid 7,000 mg; choline chloride 500,000 mg; Vit. C 10,000 mg; Iron 60,000 mg; Mn 80,000 mg; Cu 8,00 mg; Zn 50,000 mg; iodine 2,000 mg; cobalt 450 mg; Selenium 100 mg; mg 100,000 mg and antioxidant $6,000 \mathrm{mg}$

The cost of feed was determined by multiplying the quantity of each ingredient in the feed composition table with the prevailing market price per kilogram. The ingredient costs were summed up and divided by 100 to get the cost per $\mathrm{Kg}$ of the diet. The later was then multiplied by quantify of feed consumed by experimental animals to get the cost of feed per treatment diet. The Gross Income (Ending Investment) was estimated by multiplying the mean live weight of animals in each treatment by the average price per $\mathrm{Kg}$ live weight of pigs. The average price per $\mathrm{kg}$ live weight was estimated by sampling market price. Since cost of feed usually $60 \%$ of the cost of production, the later was estimated as cost of feed consumed multiplied by 1.67. Margin (Gain or Loss) was estimated as the difference between the Ending Investment (income) and the opening Investment (cost of production). The Returns on Investment (ROI) was calculated using he formulae

$$
R O I=\frac{\text { margin }}{\text { Opening Invesment }} \times 100 \%
$$

simple Annual $R O I=\left\{(1+R O I)^{\frac{1}{n}}\right\} \times 100$

Where $\mathrm{n}$ is, the period of investment (4 months for growing-finishing pigs)

The compound annual ROI, the rate of return that represents the cumulative effect that a series of gains or losses has on an Original Investment over a period of time, was calculated using the software, Financial Calculator version-v3.1.3 (Bishinews fncalculator.com)

\section{Experimental Design and Data Analyses}

At the end of the experiment, data generated were subjected to analysis of variance (ANOVA) in a Completely Randomized Design (CRD). Significantly different means were separated using Least Significant Difference method (LSD) as described by Little \& Hills (1974). The weekly performance data were plotted against age to show the trends in performance indices.

\section{Results}

The performance of experimental weaner pigs fed diets containing maize, FEMCARPP and CSM-PKC mix are shown in Table 2. The final live weights $(\mathrm{kg})$ of pigs fed diets containing FEMCARPP (9.86 and 9.42) were significantly higher $(p<0.05)$ than those fed maize based diets $(8.56)$ which was in turn superior to those fed dietary CSM-PKC mix (7.92 and 8.03). Similar pattern was also observed for the average daily weight gain of the experimental pigs. The weekly live weights of pigs in all treatment groups increased progressively with age (Figure 1). The plot of mean weights gained (Figure 2) shows that weaner pigs fed 
dietary FEMCARPP were consistently superior to those on dietary maize (control) and CSM-PKC based diets. Pigs on the CSM-PKC based diet consumed significantly $(p<0.05)$ more feed $(283.06 \mathrm{~g})$ than the control $(246.33 \mathrm{~g})$ which in turn consumed more than those fed FEMCARPP $(222.45 \mathrm{~g})$ based diets. Pigs fed diets in which maize was partially replaced $(50 \%)$ consumed significantly $(p<0.05)$ more feed than those in which maize was completely replaced by FEMCARPP. The feed conversion ratio of the pigs on dietary maize (control) (3.09) was similar $(p>0.05)$ to those fed FEMCARPP based diets (2.68 and 2.32), and both were superior to those fed the CSM-PKC based diets $(p<0.05)$. The live weights and average daily weight gains of the experimental pigs are shown in Figures 1 and 2 respectively. Though the pigs fed diets containing FERMCAP had higher weight gains throughout the experiments, the values were least at the first week of the experiment all experimental groups. Though pigs fed diets in which maize was completely replaced by FEMCARPP consumed the least amounts of feed throughout the experimental period (Figure 3), they were consistently more efficient in utilizing their feed (Figure 4).

Table 2: Performance of weaner pigs fed FEMCARPP or mixture of PKC and cassava root meal as replacement for maize

\begin{tabular}{|c|c|c|c|c|c|c|}
\hline Test Material & Maize & FEMCAR & & CSM-PKC & $\operatorname{mix}$ & SEM \\
\hline $\begin{array}{l}\text { Diets (Replacement level of } \\
\text { maize) }\end{array}$ & $A(0 \%)$ & $\begin{array}{l}\mathrm{B}(50 \\
\%)\end{array}$ & $\begin{array}{l}C \\
(100 \%)\end{array}$ & $\mathrm{D}(50 \%)$ & $\begin{array}{l}E \\
(100 \%)\end{array}$ & \\
\hline Initial live weight (Kg) & 4.66 & 4.80 & 4.72 & 4.66 & 4.91 & 0.154 \\
\hline Final live weight $(\mathrm{kg})$ & $8.57^{c}$ & $9.86^{\mathrm{a}}$ & $9.42^{b}$ & $7.92^{\mathrm{e}}$ & $8.03^{d}$ & 0.133 \\
\hline $\begin{array}{l}\text { Average daily weight gain } \\
(\mathrm{g} / \mathrm{d} / \mathrm{pig})\end{array}$ & $79.80^{c}$ & $103.27^{a}$ & $95.92^{b}$ & $66.53^{d}$ & $63.67^{d}$ & 4.219 \\
\hline $\begin{array}{l}\text { Average daily feed intake } \\
\text { (g/d/pig) }\end{array}$ & $246.33^{b}$ & $276.33^{c}$ & $222.45^{a}$ & $294.49^{c}$ & $283.06^{c}$ & 10.32 \\
\hline Feed conversion ratio & $3.09^{\mathrm{a}}$ & $2.68^{\mathrm{a}}$ & $2.32^{\mathrm{a}}$ & $4.43^{b}$ & $4.45^{\mathrm{b}}$ & 0,231 \\
\hline
\end{tabular}

a, ..., d - values within a row with different superscripts are significantly different $(p<0.05)$

The economics of feed utilization of the experimental pigs are shown in Table 3. The replacement of maize with either FEMCARPP or CSM-PKC mixture in the pig's diets reduced the cost of feed from N128.95 in diet A (control) to N113.55 in diet C (FERMCAP) and N110.25 in diet E (CSM-PKC). At the same inclusion levels, the diets containing the CSM-PKC were cheaper than those containing FERMCAPP. Partially replacing maize with FERMCAP (Diet B) increased the cost of feed consumed and hence the cost of production. The gross margin and $\mathrm{ROI}$ values of pigs fed diets $\mathrm{C}(100 \%$ replacement of maize) were superior to those on the other treatments

Table 3: Cost analysis ( $\mathrm{N}$ ) and estimated returns on investment of weaner pigs fed FEMCARPP or mixture of PKC and cassava root meal as Replacement for Maize 


\begin{tabular}{|llllll|}
\hline Test Material & Maize & FEMCARPP & \multicolumn{2}{l|}{ CSM-PKC mix } \\
\hline Diets (Replacement level of maize) & A (0\%) & B (50 \%) & C (100\%) & B (50 \%) & E (100\%) \\
\hline feed cost (N/kg) & 128.95 & 121.25 & 113.55 & 119.60 & 110.25 \\
\hline feed consumed & 13794.48 & 15474.48 & 12457.20 & 16491.44 & 15851.36 \\
\hline Cost of feed consumed & 1778.80 & 1876.28 & 1414.52 & 1972.38 & 1747.61 \\
\hline Cost of production & 5929.33 & 6254.27 & 4715.05 & 6574.59 & 5825.37 \\
\hline Feed cost per kg weight gain) & 398.46 & 324.95 & 263.44 & 529.83 & 490.61 \\
\hline Income & 8000.00 & 8000.00 & 8000.00 & 8000.00 & 8000.00 \\
\hline Gross margin & 2070.67 & 1745.73 & 3284.95 & 1425.41 & 2174.63 \\
\hline Return on Investment (ROI) (\%) & 34.92 & 27.91 & 69.67 & 21.68 & 37.33 \\
\hline Simple Annual ROI (\%) & 139.69 & 111.65 & 278.68 & 86.72 & 139.32 \\
\hline Compound Annual ROI (\%) & 231.39 & 167.70 & 728.73 & 119.22 & 255.69 \\
\hline
\end{tabular}

${ }^{1}$ based on farmgate price for grower pigs

\section{Discussion}

The superior performance of weaner pigs fed diets containing FEMCARPP over those fed diets containing CRM-PKC mix indicates that SSF has the capacity to improve digestibility and nutrients utilization of the mixture. The physicochemical characteristics of the mixture of grated cassava roots and palm kernel cake, reduction in cyanogenic glucosides levels and microbial/enzymatic degradation of structural polysaccharides in PKC must have contributed to the higher nutrients' turnover from FEMCARPP. SSF of mixture of grated cassava and PKC have been reported to increased crude protein content from 10 to 17 $\%$ and positively enhanced particle size distribution in the final product (Aladi et al., 2013, Aladi, 2016). Increased solubilisation of non-starch polysaccharides and reduction of anti-nutritive effects have been reported to occur in solid state fermented feed materials (Svanberg and Orri, 1997; Marini et al. 2008), which in turn increase nutrient digestibility and uptake by animals. Ramin et al. (2010) have reported that, treatment of PKC with microbes such as fungus and bacteria have positive effects on digestion of fibre in pigs.

Though the diets containing FEMCARPP had lower apparent metabolizable energy content than the control diets, performance of weaner pigs on diets containing the former was superior to the control. The superior FCR values shown by weaner pigs on FEMCARPP at the end of the first week of the experiment (Fig. 4) is a pointer to the possible physiological mechanism for the improved performance. According to Suiryanrayna and Ramana (2015), a growth lag phase usually occur in pigs post weaning due to limited digestive and absorptive capacity due to insufficient production of hydrochloric acid, pancreatic enzymes 
and sudden changes in feed consistency and intake The microbes implicated in the spontaneous SSF of the mixture of grated cassava and PKC; Aspergillus oryzae, A. niger, Rhizopus spp. Lactobacillus plantarum and Bifidobacterium spp. (Aladi, 2016) have been reported to possess probiotic activity (Heres et al. 2003; Niba et al. 2009a,b). The improved FCR in animals on FEMCARPP based diets could be attributed to their possible probiotic effect on the intestinal gut microflora and environment. This result is in agreement with the earlier findings of Chukwukaelo et al. (2017) who found improved performance and Aladi et al. (2017) that found that the population Salmonella spp. and E. coli was lower in the gut of broiler chickens fed FERMCAPP based diets According to Lawal et al. (2010) fungal SSF of PKC produced enzyme complexes capable of breaking down the cellulose and hemicelluloses and Hu et al. (2008) reported that feeding a diet containing solid-state fermented feed resulted to similar performance and nutrient digestibility in growing-finishing pigs fed regular diet with antibiotics. Multi-microbe probiotics prepared by SSF has been to be effective in improving performance, enhancing beneficial gut microflora and reducing harmful gut microflora in pigs (Choi et al., 2011ab; Kim et al., 2017).

The higher cost of feed consumed by pigs on diet $\mathrm{B}$, in which maize was partially replace by FERMCAP was principally due to higher quantity of feed consumed by pigs placed on the experimental diet. The pigs on diet $B$ has higher average daily feed intake $(276.33 \mathrm{~g} /$ day) relative to those fed the control (maize based) diet A ( $246.33 \mathrm{~g} /$ day). Since the diets containing FERMCAP were better utilized by the experimental pigs, this resulted in lowered cost per $\mathrm{Kg}$ body weight gain and hence superior returns on investment indices. The margin and ROI values of pigs fed diets containing CSM-PKC were comparable to the control, suggesting that though the later had superior growth performance indices, the return on the farmers investment will not be affected and hence resource poor farmers are likely to prefer CSM-PKC over maize as dietary source of energy.

\section{Conclusion And Recommendation}

These results strongly suggest that though using a mixture of cassava and palm kernel meals in a ratio of 1:1 may yield similar economic returns for weanling pigs, the use of solid-state fermented mixture of grated cassava roots and palm kernel cake (FEMCARP) will yield superior performance and economic benefit for the farmer. It is therefore recommended that resource poor pig farmers in Sub Saharan African countries can use the technology to optimize performance of their stock and profitability of their farm operations. More studies are however needed to understand the physiological basis of the improved performance of weaner pigs on FEMCARPP based diets.

\section{Declarations}

Funding: No external grant/funding was received for this work.

Conflicts of interest/Competing interests: All authors certify that as at the time of this research, they had no affiliations with or involvement in any organization or entity with any financial interest or non-financial interest in the subject matter or materials discussed in this manuscript. 
Ethics approval: The ethics governing the use and conduct of experiments on animals were strictly observed, and the experimental protocol was approved by the Research and Ethics Committee of the Department of Animal Science and Technology, Federal University of Technology, Owerri.

Consent to participate (include appropriate statements): Permission and informed consent of all persons involved in the sensory evaluation of samples was sought and freely given,

Consent for publication: This does not apply.

Availability of data and material (data transparency): The datasets generated during and/or analysed during the current study are not publicly available due data restrictions policy of the host institution, Federal University of Technology, Owerri. They can be made available from the corresponding author on reasonable request.

Code availability: This does not apply.

The authors are grateful to the Department of Animal Science and Technology and the Teaching and Research Farms, Federal University of Technology, Owerri, for the use of their personnel and facilities for this research.

\section{Contributions by Authors}

Aladi, N.O., Ukosa S.M., Ogbuewu, I.P., Okoli, I.C. and Okeudo, N.J.

NO, IC and NJ conceived and designed research. SM conducted experiments. IP and NO analyzed data and wrote the manuscript. All authors read and approved the manuscript.

\section{References}

1. Adesehinwa, A. O. (2009). Palm kernel cake supplemented with cassava flour waste as energy source for pigs. Revista Brasileira de Ciências Agrárias, 4(4), 479-484.

2. Aladi, N. O., Chukwukaelo, A. A., Okeudo, N. J., Ogbuewu, I. P., Ugwu, C. C., Etuk, E. B., \& Okoli, I. C. (2017). Blood chemistry, haematology and ileal bacteria counts of broilers fed fermented mixture of cassava root meal and palm kernel cake. Comparative Clinical Pathology, 26(6), 1273-1278. https://link.springer.com/article/10.1007/s00580-017-2519-y

3. Aladi, N.O. (2016) Studies on dietary fermented mixture of cassava and palm kernel cake on carcass characteristics of briolers and pigs. PhD Thesis submitted to the Department of Animal Science and Technology, Federal University of Technology, Owerri

4. Aladi, N.O., Isinguzo, C., Okorondu, S., Okoli, I.C \& Okeudo, N.J. (2013). Improvement on the root pulp and palm kernel cake mixture under solid state fermentation. Journal of Agricultural Technology. 9 (5), 1111-1124 
5. Amata I.A. (2014). The use of non-conventional feed resources (NCFR) for livestock feeding in the tropics. A review. Journal of Global Biosciences 3(20, 604-613.

6. Brooks, P.H., 2008. Fermented liquid feed for pigs, CAB Reviews: Perspectives in Agriculture, Veterinary Science, Nutrition and Natural Resources, http://www.cababstractsplus.org/cabreviews/, pp. 1-18.

7. Choi, J. Y., Kim, J. S., Ingale, S. L., Kim, K. H., Shinde, P. L., Kwon, I. K., \& Chae, B. J. (2011b). Effect of potential multimicrobe probiotic product processed by high drying temperature and antibiotic on performance of weanling pigs. Journal of animal science, 89(6), 1795-1804.

8. Choi. J.Y., Shinde, P.L., Ingale, S.L. Kim, J.S. Kim, Y.W. Kim, K.H. Kwonb, J.K. Chae, B.J. (2011a). Evaluation of multi-microbe probiotics prepared by submerged liquid or solid substrate fermentation and antibiotics in weaning pigs. Livestock Science 138: 144-151 http://dx.doi.org/10.1016/j.livsci.2010.12.015

9. Chukwukaelo, A., Aladi, N.O., Okeudo, N.J., Obikaonu, H.O., Ogbuewu I.P., Okoli, I.C. (2017).

Performance and meat quality characteristics of broilers fed fermented mixture of cassava roots and palm kernel cake. Tropical Animal Health and Production, 50(3), 485-493.

https://link.springer.com/article/10.1007/s11250-017-1457-7

10. Heres, L.,Wagenaar, J.A., Van Knapen, F., Urlings, B.A.P. (2003). Passage of Salmonella through the crop and gizzard of broiler chickens fed with fermented liquid feed. Avian Pathology 32, 173-181. doi:10.1080/0307945021000071597

11. Hu, J., Lu, W., Wang, C., Zhu, R., Qiao, J., 2008. Characteristics of solid-state fermented feed and its effects on performance and nutrient digestibility in growing-finishing pigs. Asian Australasian Journal of Animal Science 21, 1635-1641

12. Kim, J. S., Hosseindoust, A., Lee, S. H., Choi, Y. H., Kim, M. J., Lee, J. H., ... \& Chae, B. J. (2017). Bacteriophage cocktail and multi-strain probiotics in the feed for weanling pigs: effects on intestine morphology and targeted intestinal coliforms and Clostridium. Animal, 11(1), 45-53.

13. Lawal, T.E., Iyayi, E.A., Adeniyi, B.A. \& Adaramonye, O.A. (2010). Biodegradation of palm kernel cake with multienzyme complexes from fungi and its feeding value for broilers. International Journal of Poultry Science, 9(7), 695-701.

14. Little, T.M. and Hills, J.F. (1978). Agricultural experimentation: design and analysis. Iondon, john wiley and sons.

15. Marini, A. M., Ayub, M.Y., Abdusalam, B., Hadijah, H., Engku Azahan E.A., Ahmad, S. \& Tarmizi, J. (2008). Protein quality of Aspergillus niger fermented palm kernel cake, Tropical Agriculture and Food Science 36(2), 000-000

16. Niba, A.T., Beal, J.D., Kudi, A.C. and Brooks, P.H. (2009b). Bacterial fermentation in the gastrointestinal tract of non-ruminants: influence of fermented feeds and fermentable carbohydrates. Tropical Animal Health and Production 41, 1393-1407

17. Niba, A.T., Beal, J.D., Kudi, A.C. and Brooks, P.H. (2009a). Potential of bacterial fermentation as a biosafe method of improving feeds for pigs and poultry. African Journal of Biotechnology 8 (9), 
1758-1767.

18. Ramin, M., Alimon, A.R. \& Ivan, M. (2010). Effects of fungal treatment on the $n$ vitro digestion of palm kernel cake. Livestock Research for Rural Development 22(4),

19. Svanberg, U. \& Lorri, W. (1997). Fermentation and nutrient availability. Food Control 8 (5-6), 319-327

20. Suiryanrayna, M. V., \& Ramana, J. (2016). A review of the effects of dietary organic acids fed to swine. Journal of Animal Science and Biotechnology, 1(10).

21. Uchegbu, M.C., Etuk, E.B., Omede, A.A., Okpala, C.P., Okoli, I.C. and Opara, M. (2011). Effect of replacing maize with cassava root meal and maize/sorghum brewers' dried grains on the performance of starter broilers. Tropical and Subtropical Agroecosystems 14:363-367

22. Wadhwa, M., Bakshi, M. P. S., \& Makkar, H. P. S. (2015). Waste to worth: Fruit wastes and by-products as animal feed. CAB Reviews: Perspectives in Agriculture, Veterinary Science, Nutrition and Natural Resources, 10(031).

\section{Figures}

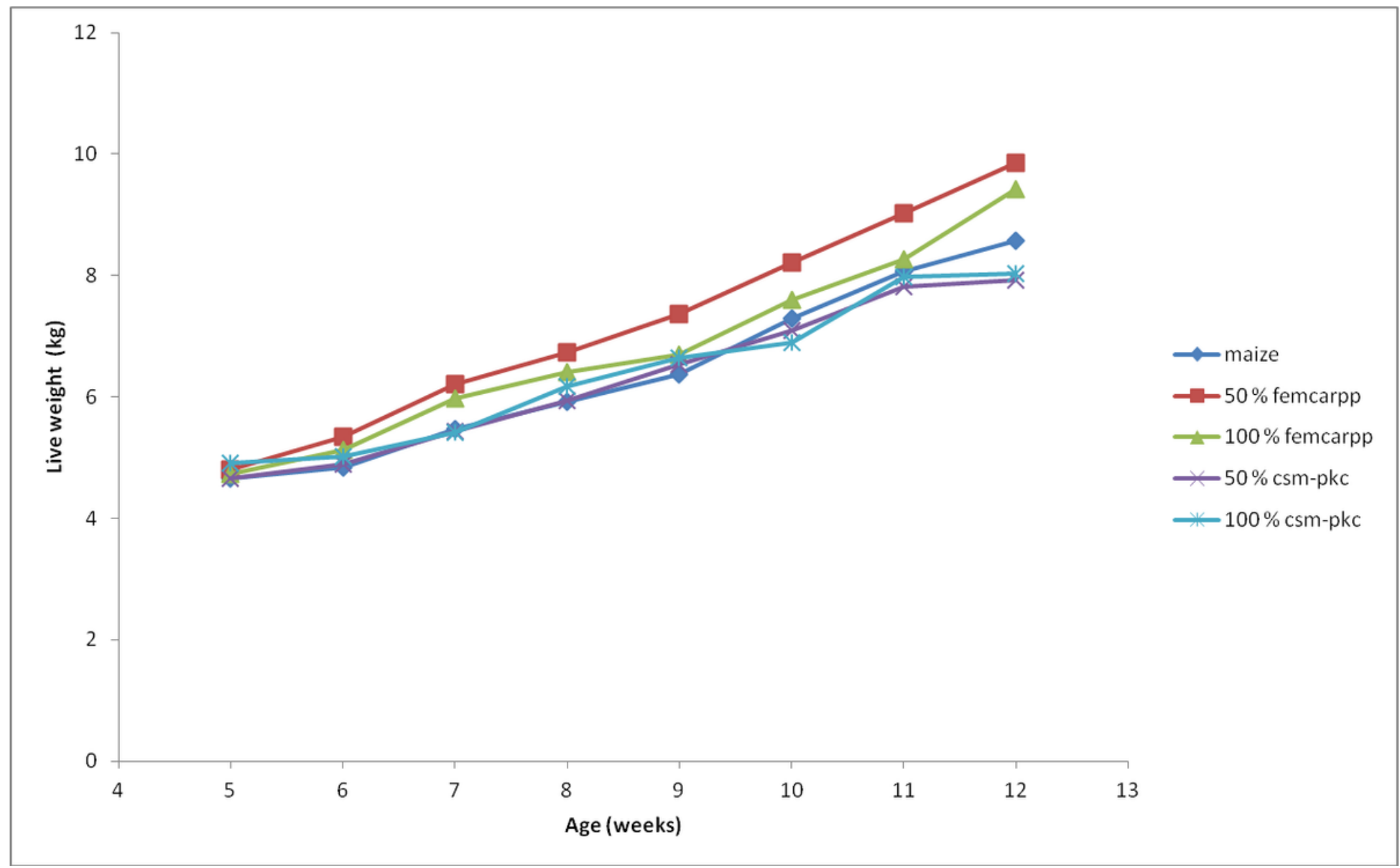

\section{Figure 1}

Graph of live weight of weaner pigs fed experimental diets against age 


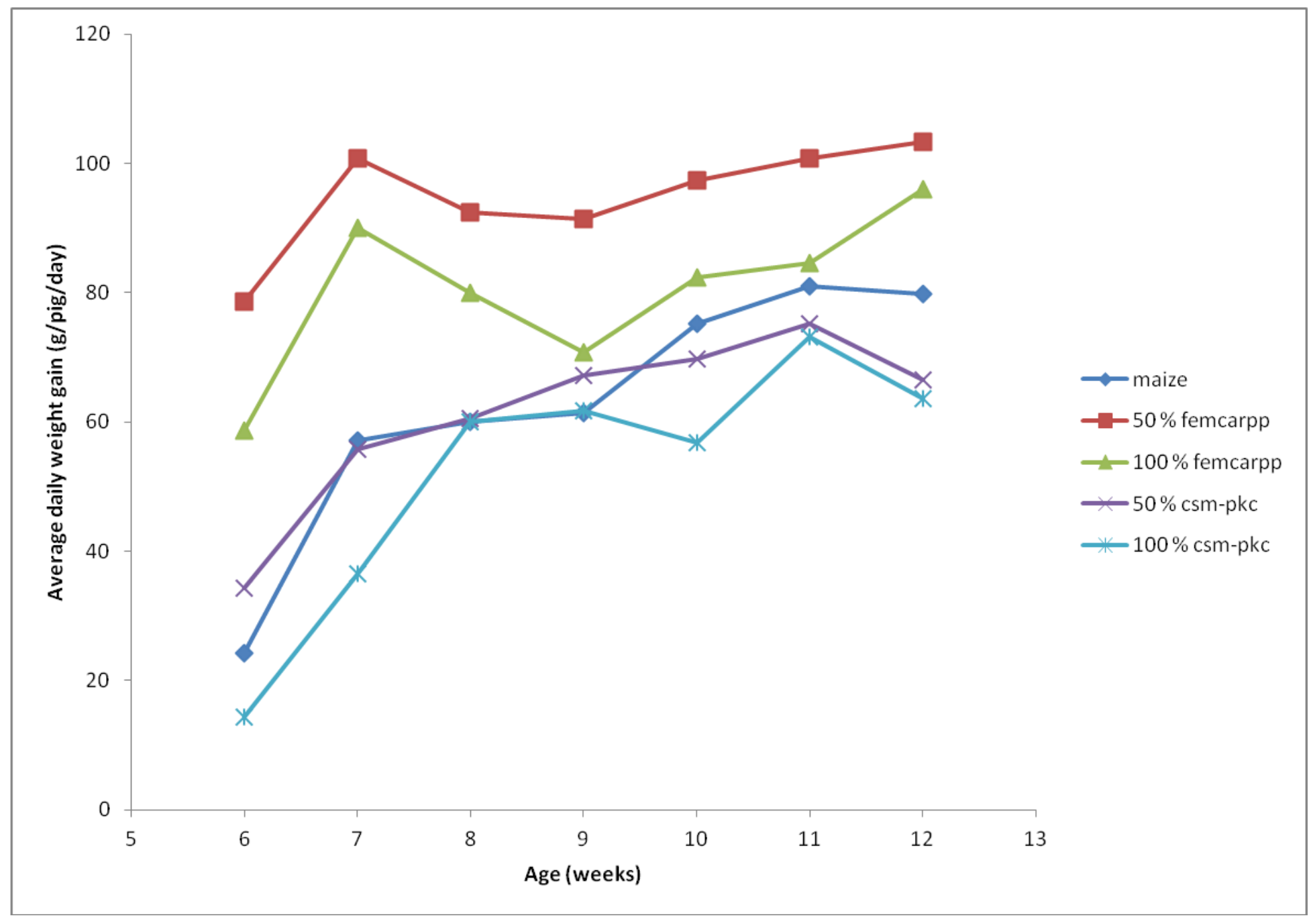

Figure 2

Average daily weight of pigs fed experimental rations with age 


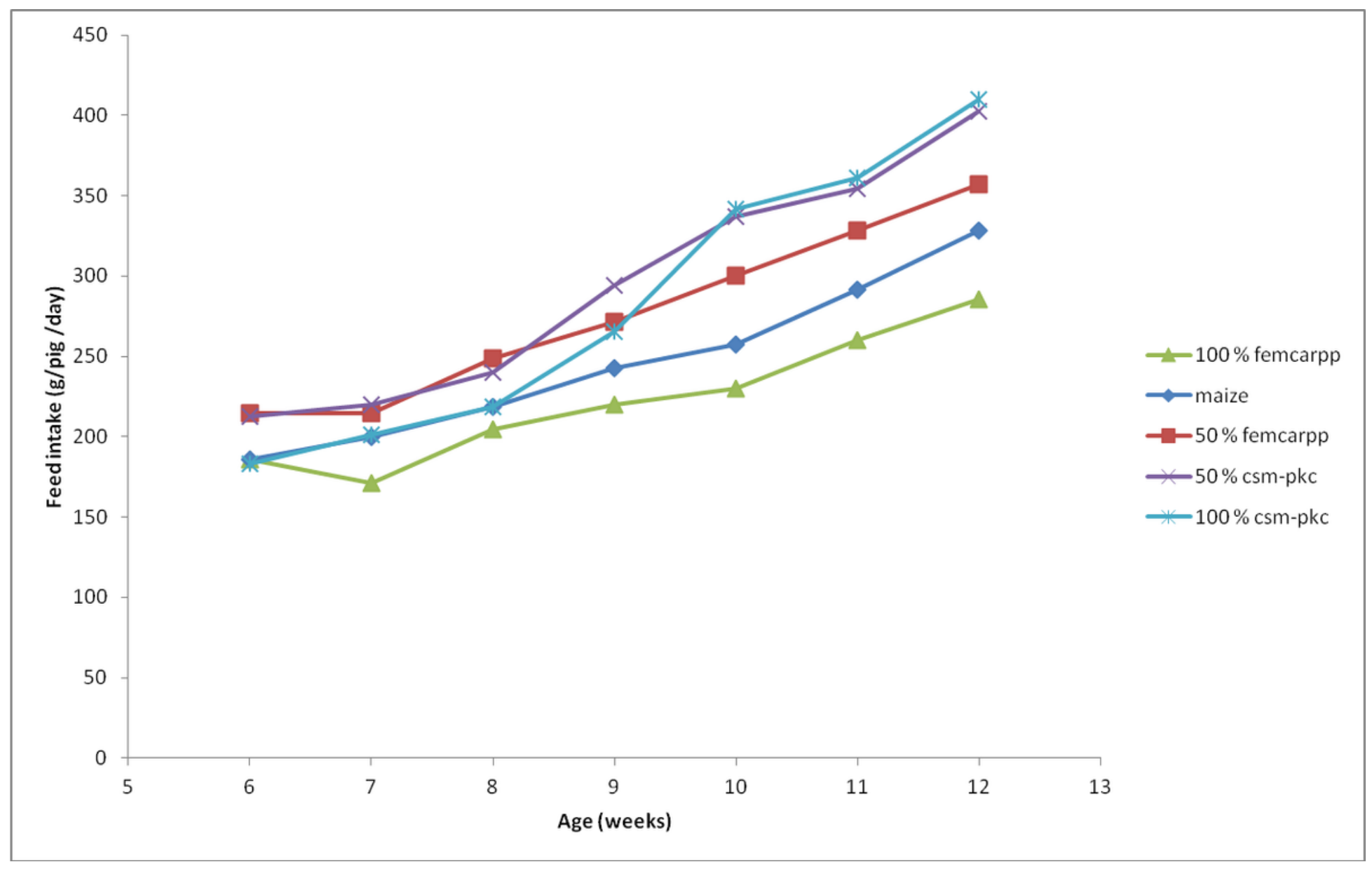

\section{Figure 3}

Graph of average daily feed intake of weaner pigs fed experimental rations plotted against age 


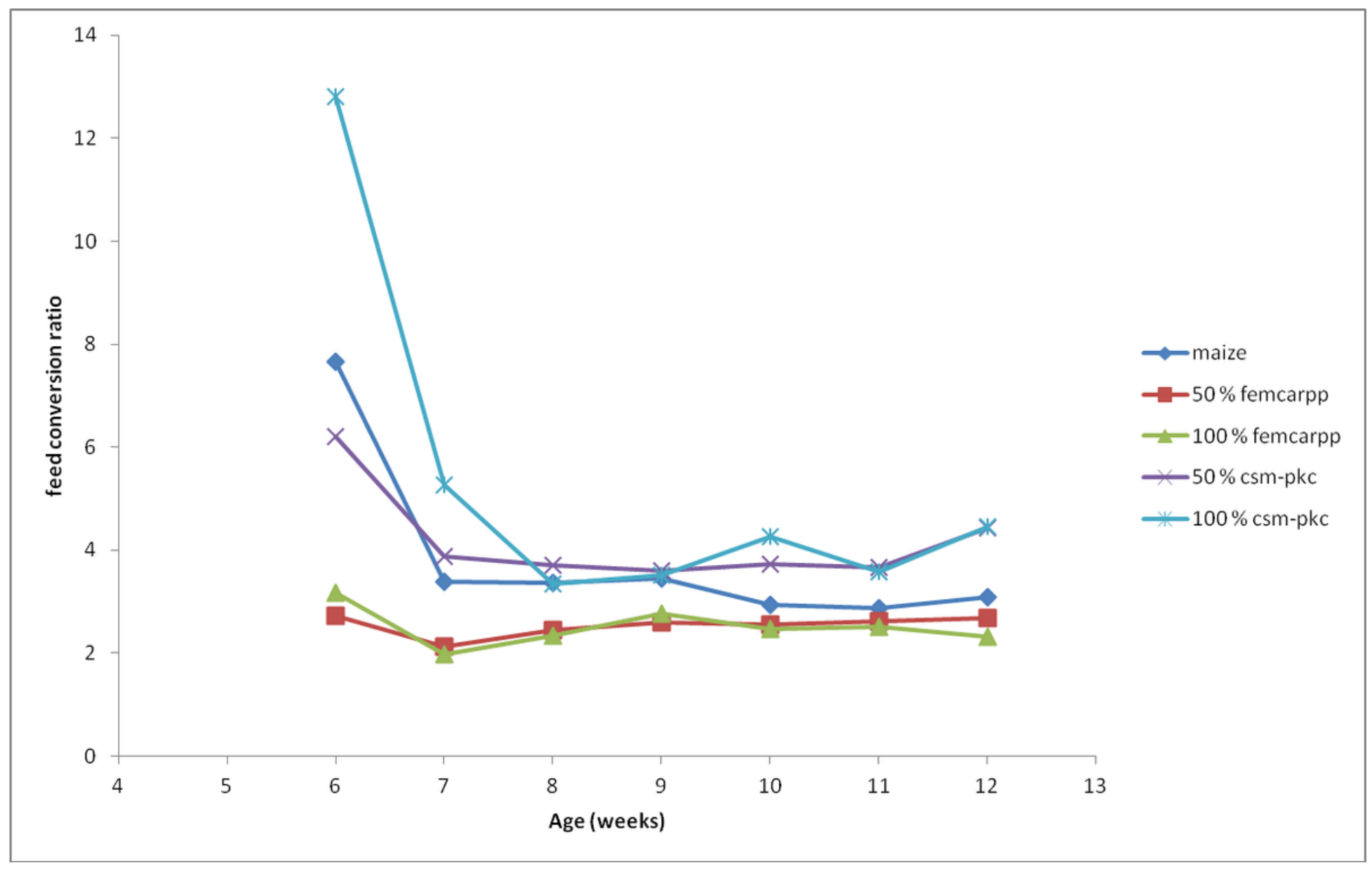

Figure 4

Graph of feed conversion ratio of weaner pigs fed experimental diets plotted against age 